\title{
Immunohistochemical analysis of retinoblastoma cell phenotype using neuronal and glial cell markers
}

\author{
Análise imuno-histoquímica do fenótipo de células de retinoblastoma utilizando marcadores \\ de células neuronais e gliais
}

María Eugenia Orellana ${ }^{1}$, Rubens Belfort Neto², Emilla Antecka ${ }^{3}$, Miguel Noel Burnier Jr. ${ }^{2,3}$

\begin{abstract}
Purpose: The cellular origin of retinoblastoma is uncertain as constituent tumor cells heterogeneously express markers of both immature and mature retinal cells. An immunohistochemical analysis of cellular origin may yield valuable insights into disease progression and treatment options. This study aimed to determine the cellular origin of retinoblastoma in a large case series and correlate these findings with histopathological prognostic factors.

Methods: Thirty-nine retinoblastoma cases were histopathologically diagnosed and analyzed by immunohistochemistry using monoclonal antibodies against the immature neural cell marker SRY-box containing gene 2 (SOX-2), the mature neuronal cell marker microtubule-associated protein 2 (MAP2), and the mature glial cell marker glial fibrillary acidic protein (GFAP). Histopathological features were also evaluated, including patterns of growth, differentiation, vitreous seeding, and choroidal/scleral, optic nerve, and anterior chamber invasion. Two retinoblastoma cell lines, WERI-1 and Y79, were studied by immunocytochemistry using the same antibodies.

Results: Expression of SOX-2 was strong in $97.4 \%$ of retinoblastoma cases, while MAP-2 was expressed in 59\% of cases. Immunostaining for GFAP was positive only in reactive stromal astrocytes interspersed amongst tumor cells and in peritumoral tissue. There was no correlation between histopathological prognostic factors and immunohistochemical markers. Retinoblastoma cell lines showed strong positivity for SOX2 (90\% of WERI- 1 cells and 70\% of Y79 cells) and MAP2 (90\% of cells in both lines). GFAP was completely negative in both cell lines.

Conclusion: The majority of retinoblastomas and both RB cell lines expressed an immature neural and/or a mature neuronal cell marker, but not a glial marker. These results indicate a typical neuroblast or neuronal origin and eliminate astrocyte differentiation from neural stem cells as the source of retinoblastoma.
\end{abstract}

Keywords: Retinoblastoma/etiology; Retinoblastoma/pathology; Phenotype; Prognosis; Immunohistochemistry; Antibodies, monoclonal

\section{RESUMO}

Objetivos: Este estudo visa determinar a origem do retinoblastoma em um número de casos e correlacionar essos achados com fatores prognósticos e histopatológicos conhecidos.

Métodos: Trinta e nove casos de retinoblastoma foram diagnosticados e analisados com imuno-histoquímica usando marcadores de anticorpos monoclonais contra as células de retina imaturas (SOX-2: SRY-box containing gene 2), contra as células da retina maturas (MAP2: microtubule-associated protein 2) e contra as células gliais maturas (GFAP: glial fibrillar acidic protein). Foram avaliadas características microscópicas dos casos (grau de diferenciação, presença de semeadura vítrea, invasão de coroide/esclera, nervo óptico e câmara anterior). Duas linhas celulares de retinoblastoma (WERI-1 e Y79) também foram testadas, utilizando os três marcadores.

Resultados: A expressão de SOX-2 foi positiva em $97,4 \%$ dos casos de retinoblastoma, enquanto MAP2 foi positivo em 59\% dos casos. GFAP foi apenas positivo no estroma (astrócitos reativos). Não houve correlação entre preditores histopatológicos e marcadores imunohistoquímicos avaliados. As linhagens celulares mostraram positividade para SOX-2 (90\% em WERI-1 e 70\% das células Y79). Ambas as linhagens celulares se mostraram fortemente positivas con MAP2 (90\%), enquanto não houve expressão de GFAP em nenhuma das linhas celulares estudadas.

Conclusões: A maioria das células de retinoblastoma desta série de casos expressa marcadores de células retinianas imaturas, além de marcadores de células maduras. As linhas celulares Y79 e WERI-1 apresentaram imunomarcação para ambos os marcadores neurais em percentagens semelhantes a dos casos avaliados. Portanto, estes resultados confirmam a origem neural do tumor em particular. Alem disso, a ausência de células positivas para GFAP no tumor descarta diferenciação de astrócitos em retinoblastoma.

Descritores: Retinoblastoma/etiologia; Retinoblastoma/patologia; Fenótipo; Prognóstico; Imuno-histoquímica; Anticorpos monclonais

\section{INTRODUCTION}

Retinoblastoma (RB) is the most common intraocular tumor in childhood ${ }^{(1,2)}$, and the vast majority of cases (about $80 \%$ ) are diagnosed before the age of three ${ }^{(3)}$. Retinoblastoma originates from a neurosensitive retina, and despite extensive study for many decades, its origin remains controversial ${ }^{(4,5)}$. Various studies posit that the retinoblastoma cell could be a primitive multipotent cell, a photoreceptor/ glial dual differentiation cell, or strictly a neuronal cell(5-10). Others propose the theory that the original cell may be a differentiated photoreceptor, specifically a cone $e^{(6,8,11,12)}$.

Several molecules have been identified that are expressed only at specific times during retinal development, suggesting utility as markers for cell type and degree of differentiation ${ }^{(13-17)}$. SOX-2 is a 317 amino acid protein belonging to the family of strong sex determining
Submitted for publication: February 3, 2016

Accepted for publication: August 28, 2016

Ocular Pathology Section, Instituto Anatomopatológico "Dr. José A. O’Daly," Universidad Central de Venezuela, Caracas, Venezuela.

${ }^{2}$ Ocular Oncology Sector, Department of Ophthalmology and Visual Sciences, Universidade Federal de São Paulo (UNIFESP), São Paulo, SP, Brazil.

3 Department of Ophthalmology and Pathology, McGill University Health Center and Henry C. Witelson

Ocular Pathology Laboratory, Montreal, Quebec, Canada.
Funding: This study was supported by Pan-American Ophthalmology Association. 2008-2009 Sean Murphy Ocular Pathology Fellowship. Montreal, QC, Canadá and Consejo de Desarrollo Científico y Humanístico de la Universidad Central de Venezuela. Caracas, Venezuela.

Disclosure of potential conflicts of interest: None of the authors have any potential conflict of interest to disclose.

Corresponding author: María Eugenia Orellana. Universidad Central de Venezuela. Instituto Anatomopatológico "Dr. José A. O’Daly", Sección de Patología Ocular. Ciudad Universitaria - Caracas 1050 - Venezuela - E-mail: euorellana@gmail.com

Approved by the following research ethics committee: Universidade Federal de São Paulo (\# 1317/10). 
region Y-box (SOX) transcription factors crucial for maintaining multipotency of neuroglial stem cells. SOX-2 is strongly expressed by neuroepithelial cells during early development of the central nervous system $^{(18)}$. Microtubule-associated protein 2 (MAP2) is a $280 \mathrm{kD}$ protein highly concentrated in the soma and dendrites of mature neurons $^{(13,14,19)}$. Glial fibrillary acidic protein (GFAP) is a marker of mature glia, including retinal glia. Studies of expression in retinoblastoma ${ }^{(7-10)}$ have detected GFAP in reactive Müller cells (reactive astrocytes) surrounding the tumor ${ }^{(13)}$.

In the current study, a series of enucleated and archived retinoblastoma samples and two RB cell lines (WERI-1 and Y79) were immunostained for markers of immature neural cells (SOX-2), mature neuronal cells (MAP2), and astroglial cells (GFAP) to examine cell origin and the relationship between marker phenotype and histopathological prognostic factors.

\section{METHODS}

Thirty-nine tissue samples of retinoblastoma added to the Henry C. Witelson Ocular Pathology Laboratory and Registry files at McGill University (Montreal, Canada) from the Instituto Anatomopatológico "Dr. José A. O'Daly" of the Universidad Central of Venezuela were selected, and clinical/epidemiological data (age, sex, and eye side) collected. No long-term clinical data were available because the request forms did not contain the information or links to access patient medical records. Thus, no comparisons that allowed determination of prognosis and survival were conducted.

Some morphological characteristics, such as differentiation status of the tumor (differentiated or un-differentiated), choroidal/scleral and optic nerve level of invasion (according to the Khelfaoui criteria) (Table 1) ${ }^{(15)}$, presence of vitreous seeding, vascular basophilia, and anterior chamber invasion were also recorded and re-evaluated.

Two human RB cell lines (WERI-1 and Y79, American Type Culture Collection, Manassas, VA, USA) were also examined for marker phenotype. These cell lines were cultivated until use according to standard procedures.

Immunohistochemistry and immunocytochemistry were conducted using an automated Benchmark ${ }^{\circledR}$ slide staining system (Ventana Medical System, Inc.; Tucson, Arizona). Immunostaining modules for SOX-2, MAP2, and GFAP were used according to protocols and instructions provided by the supplier (Ventana Medical System, Inc.). All immunostaining protocols were based on a streptavidin-biotin complex ${ }^{(20-23)}$.

\section{Table 1. Choroidal/scleral and optic nerve involvement according to} the criteria of Khelfaoui et al. ${ }^{(15)}$

Choroidal/scleral involvement Definition

No choroidal involvement

Minimal involvement

Tumor cells having destroyed Bruch's membrane without invading the choroid, with a maximum of three microscopic cell clusters

Massive involvement

Any choroidal involvement that is not minimal

Intrascleral involvement Any scleral involvement

Extrascleral involvement (i.e., microscopic orbital involvement)

\section{Optic nerve (ON) involvement}

No optic nerve involvement

Prelaminar involvement

Anterior to the lamina cribrosa

Postlaminar without invasion of the ON Within or beyond the lamina cribrosa resection line or subarachnoid space

Invasion of the resection line and/or subarachnoid space
For positive controls, SOX2 staining was confirmed in fetal retina cuts, MAP-2 staining in normal retina of the studied eyeballs, and GFAP in normal retina and optic nerve of the studied eyeballs. For negative controls, the primary antibody was omitted.

The staining intensity for all antibodies was graded from 0-3, where $0=$ negative staining, $1+=$ weak staining, $2+=$ moderate staining, and $3+=$ strong staining. Positive staining was defined as $2+$ or $3+$ intensity in the nucleus and cytoplasm for SOX-2 and in the cytoplasm for MAP2 and GFAP, while staining intensity of $0+$ or $1+$ was considered negative.

Specimens were independently analyzed by two experienced ocular pathologists (M.E.O. and M.N.B. Jr.) who rated the samples on two different occasions. They were not aware of prior medical history, the results of previous assessments, or evaluation by the other observer. Conflicts in assessment were resolved by mutual agreement between the observers, and the final decision was used for statistical analysis.

For statistical analysis, frequency and percentage of nominal and ordinal variables were calculated. Nominal variables were compared by Pearson Chi-square test. Results were considered significant when the $p$ value was less than 0.05 . The relationships between intensity of immunostaining and various histopathological parameters were assessed by correlation analysis. A $p$ value less than 0.05 was considered a statistically significant correlation.

The study protocol was approved by the ethics committees of the Federal University of São Paulo (Annex) and McGill University (McGill University Health Centre, Montreal, Canada). The use of material from the Instituto Anatomopatológico (Caracas, Venezuela) was authorized by the originating section.

\section{RESULTS}

The thirty-nine archived tissue samples were obtained from patients between 4 and 108 months of age (mean \pm SD, $24 \pm 21.8$ months; $48 \%$ female), with most cases in the range of 4 to 12 months. The series included 18 cases of well/moderately differentiated retinoblastoma (46.2\%) and 21 cases of poorly differentiated retinoblastoma (53.8\%). The level of choroidal/scleral invasion was stage I in 12 cases (30.7\%), stage II in 7 (18\%), stage III in 13 (33.3\%), stage IV in $5(12.8 \%)$, and stage $V$ in 2 cases (5.2\%). The degree of optic nerve invasion was stage I in 9 cases (23\%), stage II in 15 (38.5\%), stage III in $11(28.2 \%)$, and stage IV in 4 cases (10.3\%). Vitreous seeding was observed in 28 cases (71.8\%) and invasion of retinoblastoma tumor cells into the anterior chamber was observed in 8 cases (20.5\%). Basophilia of vascular walls, inner limiting membrane of the retina, and fibers of Zinn's zonule was observed in 18\% of cases.

Thirty-eight cases showed positive nuclear and cytoplasmic immunostaining for SOX-2 (97.4\%) and 23 cases (59\%) for MAP2. Both SOX-2 immunostaining (Figure 1) and MAP immunostaining (Figure 2) were also observed in well-differentiated tumor cells corresponding to foci of retinocytoma. Most retinoblastoma cases also showed intense cytoplasmic immunostaining for GFAP in isolated astrocytes within the tumor and in Müller cells of uncompromised retina, but tumor cells were completely negative for this marker in all cases (Figure 3).

In addition to retinoblastoma tissue, SOX-2 and MAP2 immunoreactivity were observed in normal retinal pigment epithelium, inner segments of photoreceptors, outer and inner plexiform layers of the retina, ganglion cells, nerve fiber layer, optic and ciliary nerves, nonpigmented epithelium of the ciliary body, and corneal and limbic epithelia. The optic nerve and ciliary nerves also showed positive immunostaining for GFAP. These extratumoral staining results confirm that all three antibodies efficiently recognize the intended antigens.

There were statistically significant positive associations between patient age and both SOX-2 immunostaining $(p=0.0045)$ and MAP2 immunostaining $(p=0.0311)$. In contrast, no other demographic or clinical variable was significantly associated with SOX-2 or MAP-2 expression status. 

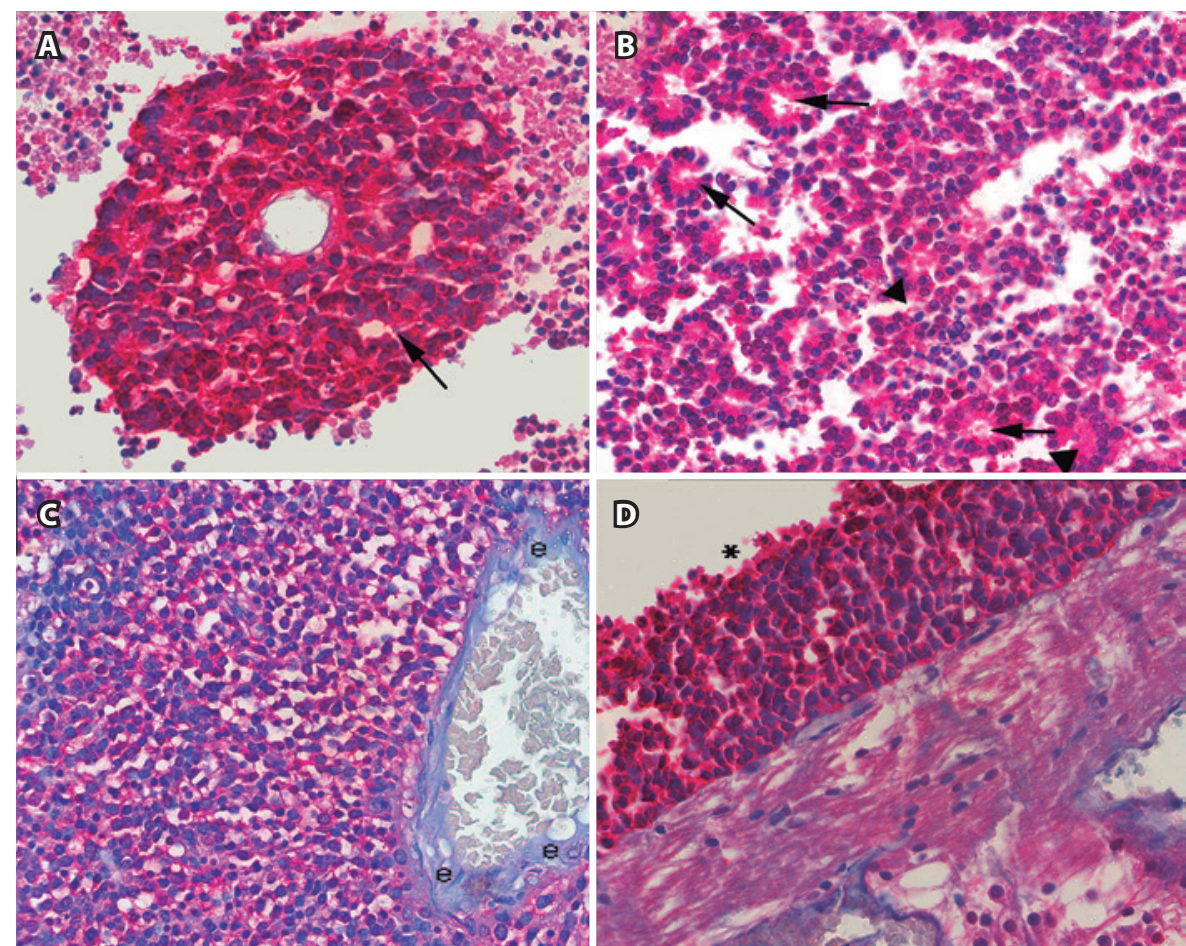

Figure 1. Immunoexpression of SOX-2 in retinoblastoma. A) Positive staining in tumor cells forming a pseudovascular rosette (arrow) (×400). B) Intense positivity in tumor cell cytoplasm from a differentiated retinoblastoma with fleurettes (arrowheads) and Flexner-Wintersteiner rosettes (arrows) $(\times 200)$. C) Positive immunostaining in an undifferentiated retinoblastoma. Adjacent endothelial cells (e) are negative ( $\times 200)$. D) Intense staining in an undifferentiated retinoblastoma located close to non-tumoral retinal internal limiting membrane and the nerve fiber layer $(\times 320)$.
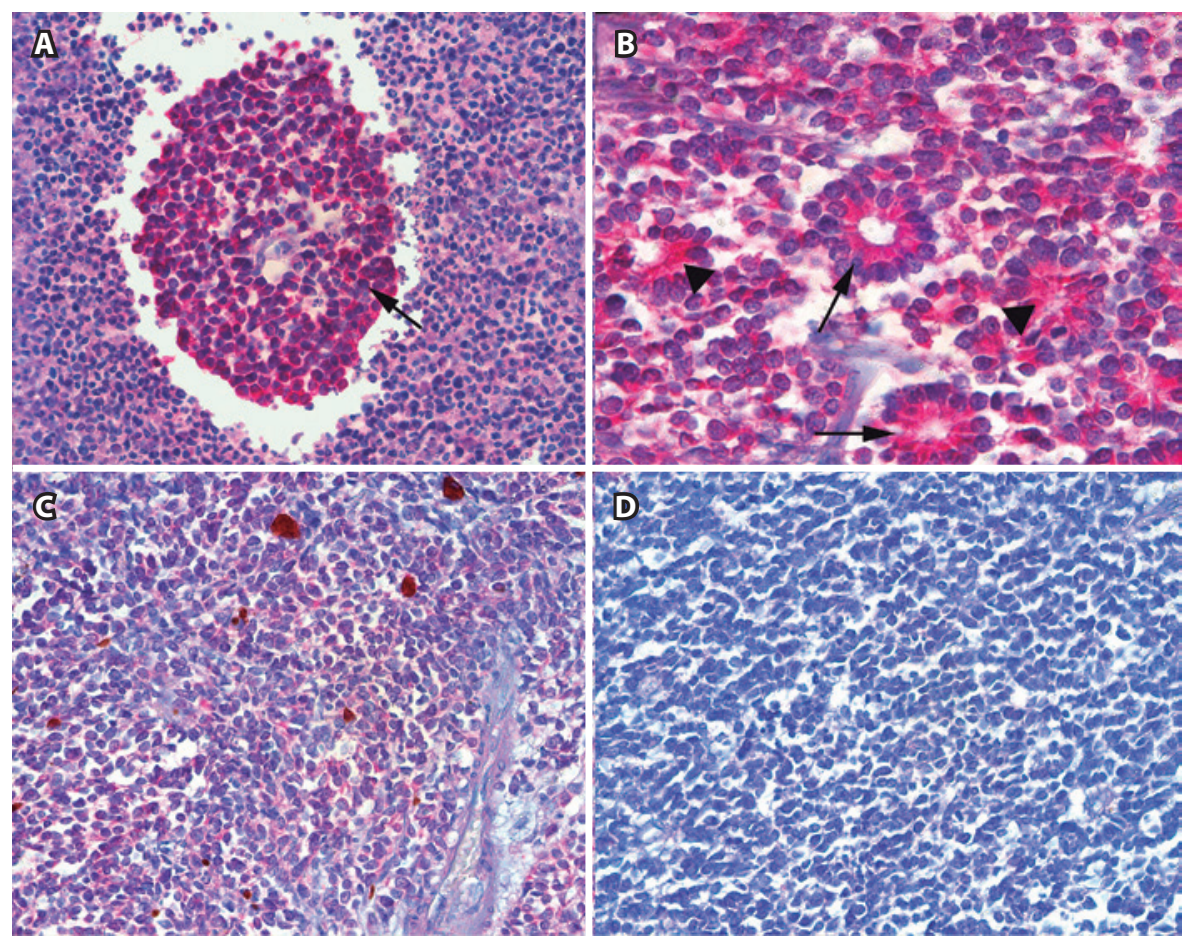

Figure 2. Immunoexpression of MAP2. A) Positive staining in tumor cells forming a pseudovascular rosette (arrow) (×320). B) Differentiated retinoblastoma with fleurettes (arrowheads) and Flexner-Wintersteiner rosettes (arrow) with intense MAP2 positivity in tumor cell cytoplasm $(\times 400)$. C) Moderate positivity in an undifferentiated retinoblastoma $(\times 400)$. D) Negative staining in an undifferentiated retinoblastoma $(\times 320)$. 

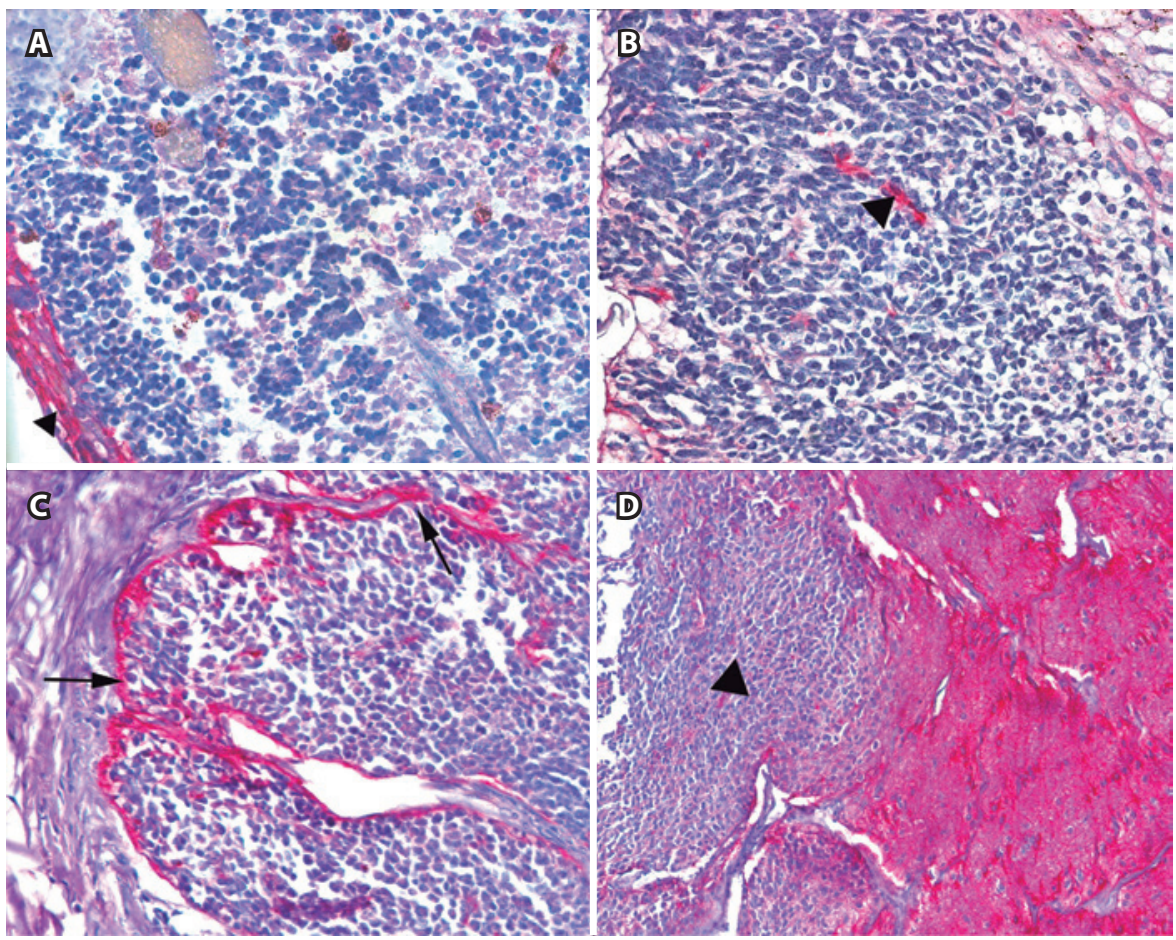

Figure 3. Immunoexpression of GFAP. A) Negative immunostaining in tumor cells of a differentiated retinoblastoma but intense positivity in peritumoral glial cells (arrowhead) $(\times 200)$. B) Negative immunostaining in tumor cells of an undifferentiated retinoblastoma with intense positivity in peritumoral glial cells (arrowhead) $(\times 320)$. C) Negative immunostaining in tumor cells of an undifferentiated retinoblastoma with intense positivity in both peritumoral and sporadic intratumoral glial cells (arrows) $(\times 200)$. D) Tumor cells located at the optic nerve (left side-arrowhead) are negative for GFAP in an undifferentiated retinoblastoma. Nerve fibers are GFAP positive (right side) $(\times 100)$.

\begin{tabular}{|c|c|c|c|}
\hline Line & SOX-2 & MAP2 & GFAP \\
\hline WERI-1 & $3+$ & $2+$ & 0 \\
\hline Y79 & $2+$ & $2+$ & 0 \\
\hline
\end{tabular}

SOX-2 = sex determining region Y-box; MAP2 = microtubule-associated protein; GFAP= glial fibrillary acidic protein.

SOX-2 was observed in cytoplasm and nucleus of both WERI-1 and Y79 retinoblastoma cell lines, with more intense immunostaining in the WERI-1 line. MAP2 staining was equivalently strong in the cytoplasm of WERI-1 and Y79 cell lines, while GFAP immunostaining was negative in both cell lines (Table 2).

\section{DISCUSSION}

Identifying the origin of retinoblastoma will advance our understanding of how cellular context influences the probability of cancer initiation and progression by specific mutations (e.g., chromosome $1 \mathrm{q}$ and $6 \mathrm{p}$ gain and $16 \mathrm{q}$ loss often associated with this tumor). Further, knowledge of cellular origin may guide treatment decisions and provide clues for improving existing therapies or developing new treatments. We found that almost all retinoblastoma samples were immunopositive for the immature neural cell marker SOX-2 and the majority of samples were immunopositive for the mature neuronal marker MAP2, including well-differentiated tumor cells. In contrast, none expressed the astroglial marker GFAP, suggesting that neuroblastoma originates from cells committed to the neuronal lineage.
During the last ten years, significant advances have been made in the epidemiology and clinical management of retinoblastoma, such as identification of histopathological markers and tumor suppressors like $\mathrm{Rb}$ protein and its associated pathways. However, the cellular origin of retinoblastoma is still controversial(4,13,24). Molnar et al. ${ }^{(9)}$ studied seven retinoblastoma cases and observed that tumor cells stained positively for myelin-associated glycoprotein (GPAM), which is only expressed in Müller cells in normal retina, whereas the same cells were negative for neuron-specific enolase (NSE) and GFAP, suggesting Müller rather than neuronal or astroglial origin. An important factor to consider, however, is the possible existence of a mixed population of cells within a tumor. Tarlton et al. studied six retinoblastomas with a panel of 18 monoclonal antibodies covering a wide range of tissue types and found marked heterogeneity within each tumor, possibly due to multiple intratumoral foci of differentiation ${ }^{(25-27)}$.

Many molecules are expressed only at specific times during retinal differentiation and can be used as specific markers for cell type and degree of differentiation. These include molecules expressed at high levels in immature retinal stem cells compared to mature retinal cells $s^{(13,28)}$. In this study, we observed that retinoblastoma tumor cells were positive for SOX-2 and MAP2, with a higher percentage immunopositive for the marker of immature neural cells (SOX) than for mature neurons (MAP2), although the difference was not statistically significant. These results are consistent with phenotypic heterogeneity and indicate that retinoblastoma is composed of cells that express markers of both differentiated and undifferentiated cells ${ }^{(29)}$. This heterogeneity should be considered when assessing the response of different cell types to potential therapeutic drugs.

Sakata et al. used nestin (a marker that decreases in expression with differentiation), HES-1 (a transcription factor regulating neuronal development), and Chx10 (a regulator of proliferation and bipolar 
cell development) to mark immature stem cells, and photoreceptor-specific nuclear receptor (PNR), GFAP, and MAP2 as markers of mature retinal cells. Five cases studied were positive for MAP2, while none were positive for GFAP, suggesting that these retinoblastomas originated from a post-mitotic neuronal cell lineage rather than a glial lineage, consistent without our observations. Seigel et al. detected subpopulations of retinoblastoma cells immunoreactive for various embryonic and neural stem cell markers and suggested that the persistence of stem cells may account for the typical early onset ${ }^{(30)}$. In the current study, we found positive correlations between immunoexpression levels of SOX-2 and MAP2 and patient age at the time of enucleation, which supports the idea that retinoblastoma cells are more likely derived from neuronal stem cells in younger patients. While none of the cases showed substantial GFAP immunoreactivity within the tumor, reactive astrocytes showing strong GFAP expression were observed in the surrounding tissue accompanying intra- and peritumoral blood vessels. In contrast, unequivocal areas of reactive gliosis have been described in retinoblastoma, generally in the presence of a disorganized retina. According to Herman et al. ${ }^{(19)}$ the reactive gliosis seen in continuity with retinoblastoma has a Müller cell proliferation pattern. In some cases, tumor growth causes the retina to rise, fold, and become disorganized, while in other tumors, retinal glia can be fully or partially surrounded by the tumor, resulting in the incorporation of isolated mature reactive astrocytes or small groups, as observed in a few of our cases. Our findings suggest that the retinoblastoma "cell of origin" does not express characteristics of mature glial cells or their direct precursors.

Numerous studies have also examined marker expression patterns in various retinoblastoma cell lines. Kyritsis et al. ${ }^{(10)}$ speculated that retinoblastoma originates from a primitive neuroectodermal bi- or pluripotential cell based on findings that the Y79 retinoblastoma cell line expresses NSE and GFAP in the undifferentiated state and one of these two markers in a more differentiated state. A previous comparative study on the immunohistochemical staining pattern of these two retinoblastoma cell lines found positivity for NSE, MAP2, homologous gene class III $\beta$ tubulin isotype (h $\beta 4$ ), and synaptophysin and negativity for opsin, GFAP, myelin basic protein, myelin-associated glycoprotein, and Leu7. The Y79 line is negative for $\mathrm{H}$ neurofilament protein (NFP-H) and S antigen, while the WERI-1 line is positive for both, suggesting that WERI- 1 is in a more advanced state of differentiation. Nonetheless, the presence of MAP2 immunoreactivity in both cell lines supports the hypothesis that both arise from mature neuroblasts ${ }^{(19)}$. More recently, Seigel et al. reported the expression of stem cell markers in WERI-1 and Y79. This finding may have important clinical implications because stem cell properties could allow retinoblastoma subpopulations to endure chemotherapy and retain tumor forming potential(30). In the present study, we observed that both Y79 and WERI-1 lines were positive with varying intensity (moderate to intense) for SOX-2 and MAP2 and negative for GFAP, consistent with neuroblast origin. The presence of immature and mature neural markers in these lines corroborates our immunohistochemical findings and again suggests that retinoblastoma may originate from a multipotent neuronal cell lineage that retains some phenotypic heterogeneity.

Two important aspects of this research are (1) the co-application of two neural markers (for immature and mature cells) and a broad spectrum glial marker in a relatively large sample of retinoblastoma cases, and (2) direct comparison with retinoblastoma cell lines. Based on the heterogeneous phenotype of retinoblastoma, it may be necessary to design new treatment protocols using agents able to disrupt proliferation and destroy multiple subpopulations, including hybrid phenotypes.

In conclusion, the immunohistochemical expression of SOX-2 and MAP2 in retinoblastoma indicates a neuroblast/neuronal origin, while GFAP negativity rules out a glial origin. No correlations were found between immunohistochemical expression levels (of SOX-2 and MAP2) and prognostic factors, suggesting these are ubiquitous features of retinoblastoma. The immunocytochemical expression pattern of SOX-2, MAP2, and GFAP in retinoblastoma cell lines (Y79 and WERI-1) further supports the neuroblast/neuronal origin of retinoblastoma.

\section{REFERENCES}

1. Abramson DH. Retinoblastoma in the 20th century: past success and future challenges the Weisenfeld lecture. Invest Ophthalmol Vis Sci. 2005;46(8):2683-91.

2. Abramson DH. Periocular chemotherapy for retinoblastoma: success with problems? Arch Ophthalmol. 2005:123(1):128-9; author reply 9.

3. Chintagumpala M, Chevez-Barrios P, Paysse EA, Plon SE, Hurwitz R. Retinoblastoma: review of current management. Oncologist. 2007;12(10):1237-46.

4. Dyer MA, Bremner R. The search for the retinoblastoma cell of origin. Nat Rev Cancer. 2005;5(2):91-101.

5. Tsokos M, Kyritsis AP, Chader GJ, Triche TJ. Differentiation of human retinoblastoma in vitro into cell types with characteristics observed in embryonal or mature retina. Am J Pathol. 1986;123(3):542-52.

6. Rodrigues MM, Wiggert B, Shields J, Donoso L, Bardenstein D, Katz N, et al. Retinoblastoma. immunohistochemistry and cell differentiation. Ophthalmology. 1987;94(4): 378-87.

7. Messmer EP, Font RL, Kirkpatrick JB, Hopping W. Immunohistochemical demonstration of neuronal and astrocytic differentiation in retinoblastoma. Ophthalmology. 1985; 92(1):167-73.

8. Gonzalez-Fernandez F, Lopes MB, Garcia-Fernandez JM, Foster RG, De Grip WJ, Rosemberg $\mathrm{S}$, et al. Expression of developmentally defined retinal phenotypes in the histogenesis of retinoblastoma. Am J Pathol. 1992;141(2):363-75.

9. Molnar ML, Stefansson K, Marton LS, Tripathi RS, Molnar GK. Immunohistochemistry of retinoblastomas in humans. Am J Ophthalmol. 1984;97(3):301-7.

10. Kyritsis AP, Tsokos M, Triche TJ, Chader GJ. Retinoblastoma--origin from a primitive neuroectodermal cell? Nature. 1984;307(5950):471-3.

11. Mirshahi M, Boucheix C, Dhermy P, Haye C, Faure JP. Expression of the photoreceptorspecific S-antigen in human retinoblastoma. Cancer. 1986;57(8):1497-500.

12. Bogenmann E, Lochrie MA, Simon MI. Cone cell-specific genes expressed in retinoblastoma. Science. 1988;240(4848):76-8.

13. Sakata $R$, Yanagi Y. Expression of immature and mature retinal cell markers in retinoblastoma. Eye. 2008;22(5):678-83

14. Tropepe V, Coles BL, Chiasson BJ, Horsford DJ, Elia AJ, Mclnnes RR, et al. Retinal stem cells in the adult mammalian eye. Science. 2000;287(5460):2032-6.

15. Khelfaoui F, Validire P, Auperin A, Quintana E, Michon J, Pacquement H, et al. Histopathologic risk factors in retinoblastoma: a retrospective study of 172 patients treated in a single institution. Cancer. 1996;77(6):1206-13.

16. Burmeister M, Novak J, Liang MY, Basu S, Ploder L, Hawes NL, et al. Ocular retardation mouse caused by Chx10 homeobox null allele: impaired retinal progenitor proliferation and bipolar cell differentiation. Nat Genet. 1996;12(4):376-84.

17. Liu IS, Chen JD, Ploder L, Vidgen D, van der Kooy D, Kalnins VI, et al. Developmental expression of a novel murine homeobox gene (Chx10): evidence for roles in determination of the neuroretina and inner nuclear layer. Neuron. 1994:13(2):377-93.

18. Phi JH, Park SH, Kim SK, Paek SH, Kim JH, Lee YJ, et al. SOX-2 expression in brain tumors: a reflection of the neuroglial differentiation pathway. Am J Surg Pathol. 2008;32(1):103-12.

19. Herman MM, Perentes E, Katsetos CD, Darcel F, Frankfurter A, Collins VP, et al. Neuroblastic differentiation potential of the human retinoblastoma cell lines Y-79 and WERI-Rb1 maintained in an organ culture system. An immunohistochemical, electron microscopic, and biochemical study. Am J Pathol. 1989;134(1):115-32.

20. Taylor CR, Barr NJ, Wu N. Techniques of immunohistochemistry: principles, pitfalls and standarization. In: DJ D, editor. Diagnostic immunohistochemistry. Pittsburgh PA: Churchill-Livingstone; 2006. p.1-42.

21. Eagle RC Jr. Immunohistochemistry in diagnostic ophthalmic pathology: a review. Clin Experiment Ophthalmol. 2008:36(7):675-88

22. White V. Advanced diagnostic techniques - diagnostic immunohistochemistry. In: Albert DM JF, editor. Principles and practice of ophthalmology: clinical practice. $2^{\text {nd }}$ ed. Philadelphia, PA: Saunders; 1994. p.2372-85.

23. Murphree L. Tumors of the retina. In: SJ R, editor. Retina. Philadelphia, PA: Elsevier; 2006. p.557-607.

24. Nork TM, Schwartz TL, Doshi HM, Millecchia LL. Retinoblastoma. Cell of origin. Arch Ophthalmol. 1995;113(6):791-802.

25. Ts'o MO, Zimmerman LE, Fine BS. The nature of retinoblastoma. I. Photoreceptor differentiation: a clinical and histopathologic study. Am J Ophthalmol. 1970:69(3):339-49.

26. Ts'o MO, Fine BS, Zimmerman LE. The nature of retinoblastoma. II. Photoreceptor differentiation: an electron microscopic study. Am J Ophthalmol. 1970;69(3):350-9.

27. Tarlton JF, Easty DL. Immunohistological characterization of retinoblastoma and related ocular tissue. Br J Ophthalmol. 1990;74(3):144-9.

28. Ma B, Lei X, Guan Y, Mou L, Yuan Y, Yue H, et al. Maintenance of retinal cancer stem cell-like properties through long-term serum-free cultura from human retinoblastoma. Oncol Rep. 2011;26(1):135-43.

29. Zhong $X$, Li Y, Peng F, Huang B, Lin J, Zhang W, et al. Identification of tumorigenic retinal stem-like cells in human solid retinoblastomas. Int J Cancer. 2007:121(10):2125-31.

30. Seigel GM, Hackam AS, Ganguly A, Mandell LM, Gonzalez-Fernandez F. Human embryonic and neuronal stem cell markers in retinoblastoma. Mol Vis. 2007;13:823-32. 